\title{
Pengaruh Pemberiaan Sarang Telur Laba-laba (Spider Silk Protein) Menemerus Bivittatus Secara Topikal Terhadap Penyembuhan Luka Insisi pada Fase Inflamasi Tikus Putih Jantan (Rattus Norvegicus) Strain Wistar
}

\author{
Muhammad Yusak Alfaris ${ }^{1}$, Mas Mansyur ${ }^{2 *}$ \\ Fakultas Kedokteran Universitas Wijaya Kusuma Surabaya ${ }^{1}$ \\ Bagian Biomedik Penelitian Biomolekuler Fakultas Kedokteran Universitas Wijaya \\ Kusuma Surabaya ${ }^{2}$ \\ e-mail: cakmansyur@gmail.com
}

\begin{abstract}
Abstrak
Penyembuhan luka merupakan proses alamiah dari tubuh, namun seringkali dilakukan pemberian obat-obatan, salah satunya pemanfaatan sarang laba-laba. Tujuan penelitian ini adalah untuk mengetahui pengaruh pemberian sarang telur laba-laba (Spider silk protein) M enemerus bivittatus secara topikal terhadap penyembuhan luka insisi pada fase inflamasi. Penelitian ini bersifat Eksperimental Laboratoris. Subyek penelitiaan adalah 18 ekor tikus wistar (rattus norvegicus strain) yang diberi 2 macam perlakuaan, yaitu kontrol (K1) dengan pemberiaan normal salin dan perlakuan (P1) dengan pemberiaan sarang telur laba-laba (spider silk protein) Menemerus bivittatus secara topikal serta luka ditutupi dengan Hipafik. Pemilihan sampel dilakukan secara randomisasi dengan cara simple random sampling. Uji hipotesis menggunakan uji Chi Square dengan $\alpha=0.05$. Hasil penelitian menunjukkan bahwa ada pengaruh pemberian sarang telur laba-laba (spider silk protein) secara topikal terhadap proses penyembuhan luka insisi $(p=0,005)$ pada fase inflamasi $(p=0,000)$ pada tikus putih jantan (Rattus norvegicus wistar).
\end{abstract}

Kata Kunci: Luka insisi, sarang telur laba-laba, fase inflamasi.

\section{The Effect of Spider (Menemerus Bivittatus) Silk Protein Topically Administration for Healing of Incision wound on Inflammatory phase of (Rattus Norvegicus) Strain Wistar}

\begin{abstract}
The healing of wounds is a natural process of the human body but often medicine is used, for example the use of spider silk. The purpose of this research is to know the effect of the use of spider (M enemerus Bivittatus) silk protein used topically for the healing of incision wounds in the inflammatory phase. This research is a laboratory experiment. The subjects of this research are 18 wistar rats (Rattus Norvegicus strain) that are treated in two different ways. The first is control (K1) with the use of normal saline and the second is treatment (PI) with the use of spider silk protein topically using wound dressing. The selection of samples is done randomly using the simple random sampling. The hypothesis testing uses the Chi Square testing with $\alpha=0.05$. The results of this research shows that the use of spider silk protein topically effects the process of incision wound healing $(0,005)$ in the inflammatory phase $(0,000)$ on Wistar rats.
\end{abstract}

Keywords: incision wound, spider silk protein, inflammatory phase 


\section{PENDAHULUAN}

Kulit merupakan organ terluas di tubuh, yang berfungsi sebagai pertahanan mekanis antara lingkungan eksternal dengan jaringan di bawahnya, tetapi secara dinamis juga berfungsi dalam berbagai pertahanan terhadap infeksi, termoregulator dan berbagai fungsi penting lainnya (1). Ketika fungsi kulit terganggu karena penyebab infeksi seperti bisul, luka bakar, neoplams atau trauma maka fungsi tersebut tidak lagi memadai dilakukan. Oleh karena itu penting untuk mengembalikan integritasnya sesegera mungkin (2). Luka adalah hilang atau rusaknya sebagian jaringan tubuh. Keadaan ini dapat disebabkan oleh trauma benda tajam atau tumpul, perubahan suhu, zat kimia, ledakan, sengatan listrik, atau gigitan hewan (3). Ada beberapa proses biologis tubuh dalam menyembuhkan luka melalui beberapa tahapan, yaitu: hemostasis, inflamasi, proliferasi, dan remodeling(4).

Penyembuhan luka adalah suatu bentuk proses usaha untuk memperbaiki kerusakan yang terjadi. Komponen utama dalam proses penyembuhan luka adalah kolagen disamping sel epitel. Fibroblas adalah sel yang bertanggung jawab untuk sintesis kolagen (5). Luka sering ditandai dengan adanya tepi luka yang meninggi dan jaringan yang hiperproliferatif. Fibroblas yang berasal dari luka kronis bersifat prematur dan memiliki sifat yang berbeda sehingga responnya terhadap stimulasi yang normal menjadi tidak efisien $(6,7,8)$. Banyak pengobatan luka menurut dengan menggunakan zat kimia yang memberikan hasil baik. Menurut BPOM RI(9), 2010, Penggunaan tumbuhan obat di Indonesia dalam upaya pemeliharaan kesehatan, maupun sebagai pengobatan menggunakan tumbuhan obat kecenderungannya terus meningkat terutama sejak krisis ekonomi tahun 1997 yang menyebabkan harga obat sintetik melonjak sangat tinggi karena sebagian besar bahan bakunya masih diimpor. Seiring dengan hal itu, penelitian yang membuktikan khasiat dan keamanan obat tradisional atau obat asli Indonesia juga meningkat.

World Health Organization (WHO) merekomendasikan penggunaan obat tradisional termasuk herbal dalam pemeliharaan kesehatan masyarakat, pencegahan dan pengobatan penyakit, terutama untuk penyakit kronis, penyakit degeneratif dan kanker(10). Pasien dengan luka kronis sering diobati dengan baik terapi antimikroba sistemik atau topikal. Dua penelitian di Eropa menemukan bahwa diatas $60 \%$ dari pasien ini telah menerima beberapa bentuk terapi antibiotik dalam 6-12 bulan sebelumnya, biasanya untuk jangka waktu yang lama $(11,12)$. Banyak penelitian tentang penyembuhan luka dengan menggunakan pengobatan tradisional dan obat herbal dengan hasil baik, diantranya adalah: menurut Isrofah dkk (2015), tidak ditemukan adanya perbedaan yang signifikan penyembuhan luka bakar derajat II termal pada tikus putih secara makroskopis sedangkan pada pengamatan mikroskopis ditemukan perbedaan yang signifikan pada angiogenesis (13). Berdasarkan gambaran klinis SEDB $40 \%$ mempunyai gambaran klinis penyembuhan luka bakar derajat II termal lebih baik. Menurut Wirastuty (2016), Ekstrak kulit batang kayu jawa (Lannea Coromandelica) dalam bentuk sediaan gel dapat memberikan efek terhadap luka bakar pada kelinci (Oryctolagus cuniculu), efek terbaik pada konsentrasi 3\% (14). Penelitian ini bertujuan untuk menemukan pengaruh pemberiaan sarang telur laba-laba (Spider Silk Protein) menemerus bivittatus secara topikal terhadap penyembuhan luka insisi pada fase iinflamasi tikus putih jantan (Rattus Norvegicus Strain Wistar).

\section{BAHAN DAN METODE}

Penelitian ini merupakan penelitian Eksperimental Laboratoris. Subyek penelitian adalah tikus wistar (rattus norvegicus strain) yang diberi 2 macam perlakuaan, yaitu kontrol (K1) dengan pemberiaan normal salin dan perlakuan (P1) dengan pemberiaan sarang telur laba-laba (spider silk protein) Menemerus bivittatus secara topikal serta luka ditutupi dengan Hipafik. Populasi dalam penelitian ini adalah tikus putih jantan (Rattus norvegicus wistar), usia 2-3 bulan, berat badan antara 120200 gram, jenis kelamin jantan, Jumlah sampel secara keseluruhan ada 18 ekor tikus putih jantan yang telah diberi luka insisi. 9 ekor digunakan sebagai kontrol (K), dan 9 ekor digunakan sebagai perlakuan (P). teknik pengambilan sampel dari populasi menggunakan cara simple random sampling. Kondisi tikus sebelum diberi perlakuan makanan dan minuman yang sama, perawatan 
dan sanitasi kandang, kondisi (sehat dan tidak mendapatkan pengobatan sebelumnya), masa adaptasi yang sama yaitu 5 hari, pembuatan luka insisi pada tikus, lokasi luka, diameter dan kedalaman luka yang sama, pemberian identitas pada tikus.

Instrumen yang digunakan untuk menilai proses penyembuhan luka adalah lembar observasi yang dimodifikasi dari Watono.

\section{HASIL}

Tabel 1. Hasil pengamatan hari ke 2

\begin{tabular}{|c|c|c|c|c|}
\hline \multicolumn{5}{|c|}{ HASIL HARI KE 2} \\
\hline \multirow{2}{*}{\multicolumn{2}{|c|}{ Pengamatan }} & \multicolumn{2}{|c|}{ Kelompok } & \multirow{2}{*}{ Total } \\
\hline & & Perlakuan & Kontrol & \\
\hline \multirow{3}{*}{$\begin{array}{l}\frac{8}{2} \\
\frac{9}{0} \\
\frac{1}{3}\end{array}$} & Tidak ada cairan & 5 & 0 & 5 \\
\hline & Ada cairan & 4 & 5 & 9 \\
\hline & $\begin{array}{l}\text { Ada cairan } \\
\text { dengan pus }\end{array}$ & 0 & 4 & 4 \\
\hline \multirow{3}{*}{$\frac{0}{0}$} & $\begin{array}{l}\text { Tidak ada } \\
\text { edema }\end{array}$ & 6 & 0 & 6 \\
\hline & $\begin{array}{l}\text { Diameter 0,6- } \\
2 \mathrm{~cm}\end{array}$ & 3 & 5 & 8 \\
\hline & Diameter $>2 \mathrm{~cm}$ & 0 & 4 & 4 \\
\hline \multirow{3}{*}{$\begin{array}{l}\frac{5}{10} \\
\frac{2}{0} \\
\frac{0}{d 1} \\
\frac{11}{11}\end{array}$} & $\begin{array}{l}\text { Tidak ada } \\
\text { Kemerahan }\end{array}$ & 3 & 0 & 3 \\
\hline & $\begin{array}{l}\text { Diameter 0,6- } \\
2 \mathrm{~cm}\end{array}$ & 6 & 1 & 7 \\
\hline & Diameter $>2 \mathrm{~cm}$ & 0 & 8 & 8 \\
\hline & Total & 27 & 27 & 54 \\
\hline
\end{tabular}

Tabel 2. Hasil pengamatan hari ke 4

\begin{tabular}{|c|c|c|c|c|}
\hline \multicolumn{5}{|c|}{ HASIL HARI KE 4} \\
\hline & \multirow{2}{*}{ Pengamatan } & \multicolumn{2}{|c|}{ Kelompok } & \multirow{2}{*}{ Total } \\
\hline & & Perlakuan & Kontrol & \\
\hline \multirow{3}{*}{ 过 } & Tidak ada cairan & 6 & 0 & 6 \\
\hline & Ada cairan & 3 & 6 & 9 \\
\hline & $\begin{array}{l}\text { Ada cairan } \\
\text { dengan pus }\end{array}$ & 0 & 3 & 3 \\
\hline \multirow{3}{*}{ 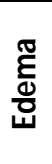 } & Tidak ada edema & 8 & 0 & 8 \\
\hline & $\begin{array}{l}\text { Diameter 0,6- } \\
2 \mathrm{~cm}\end{array}$ & 1 & 7 & 8 \\
\hline & Diameter >2cm & 0 & 2 & 2 \\
\hline \multirow{3}{*}{$\frac{5}{10}$} & $\begin{array}{l}\text { Tidak ada } \\
\text { Kemerahan }\end{array}$ & 6 & 0 & 6 \\
\hline & $\begin{array}{l}\text { Diameter 0,6- } \\
2 \mathrm{~cm}\end{array}$ & 3 & 3 & 6 \\
\hline & Diameter $>2 \mathrm{~cm}$ & 0 & 6 & 6 \\
\hline & Total & 27 & 27 & 54 \\
\hline
\end{tabular}

Lembar observasi berisi proses penyembuhan dari Gaylene. Evaluasi penyembuhan luka dilakukan pada hari ke 2 dan ke 4. Analisis data untuk menguji hipotesis penelitian menggunakan uji Chi Square dengan bantuan software SPSS 21.0 dengan tingkat signifikan $\alpha$ $=0,05$. Hipotesa alternatif diterima jika $p<\alpha$

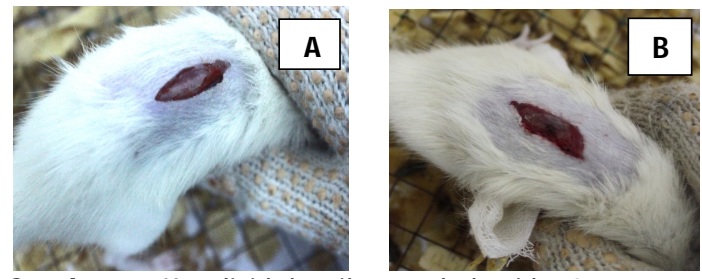

Gambar 1. Kondisi luka tikus pada hari ke 2. A. tikus perlakuan B. tikus kontrol.

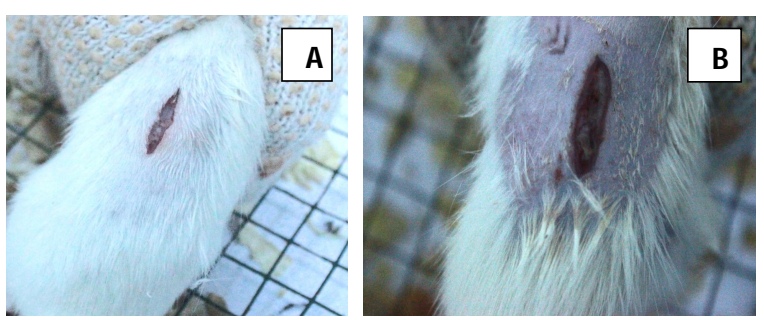

Gambar 2. Kondisi luka tikus pada hari ke 4. A. tikus perlakuan B. tikus kontrol. 


\section{Hasil rekapitulasi inflamasi}

Tabel 3. luka dalam kondisi inflamasi

\begin{tabular}{cccc}
\hline Inflamasi & \multicolumn{2}{c}{ Kelompok } & Total \\
\cline { 2 - 3 } & Kontrol & Perlakuan & \\
\hline Tidak inflamasi & 0 & 4 & 4 \\
Inflamasi ringan & 3 & 5 & 8 \\
Inflamasi sedang & 6 & 0 & 6 \\
\hline Total & 9 & 9 & 18 \\
\hline
\end{tabular}

Tabel 4 Hasil Uji Friedman

\begin{tabular}{cc}
\hline Chi-Square & 32.378 \\
\hline$p$ & 0.000 \\
\hline
\end{tabular}

Tabel 5. Hasil Tabulasi Silang Kelompok dengan Penyembuhan

\begin{tabular}{ccccc}
\hline Penyembuhan & \multicolumn{2}{c}{ Kelompok } & Total & p \\
\cline { 2 - 3 } & Kontrol & Perlakuan & & \\
\hline Cepat & 0 & 4 & 4 & \\
Sedang & 3 & 5 & 8 & 0.005 \\
Lambat & 6 & 0 & 6 & \\
\hline Total & 9 & 9 & 18 & \\
\hline
\end{tabular}

\section{Hasil pengamatan ditampilkan dalam diagram batang}
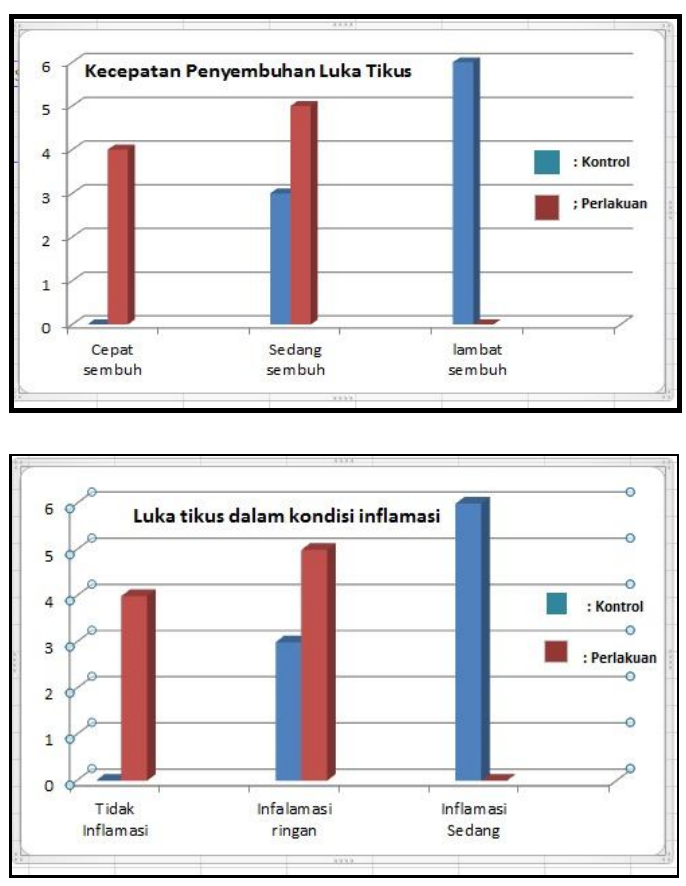

\section{PEMBAHASAN}

Hasil penelitian berdasarkan inflamasi (Tabel 3) pada kelompok perlakuan yang tidak inflamasi sebanyak 4 ekor, inflamasi ringan sebanyak 5 ekor, dan inflamasi sedang sebanyak nol ekor. Sedangkan pada kelompok kontrol yang tidak inflamasi sebanyak nol ekor, inflamasi ringan sebanyak 3 ekor, dan inflamsi sedang sebanyak 6 ekor. Dari hasil uji chi square diperoleh $p=0,000$, sehingga $p<\alpha$, hal ini berarti ada pengaruh yang sangat signifikan antara terjadinya inflamasi dengan dengan pemberian telur sarang laba-laba. Berdasarkan hasil penelitian yang didapatkan (tabel 5) pada kelompok perlakuan dengan penyembuhan luka yang cepat sebanyak 4 ekor, cukup sebanyak 5 ekor dan lambat sebanyak nol ekor. Sedangkan pada kelompok kontrol dengan penyembuhan luka yang cepat sebanyak nol ekor, cukup sebanyak 3 ekor, dan lambat sebanyak 6 ekor. Sedangkan hasil statistik dengan uji Chi Square didapatkan nilai $p$ sebesar 0.005. ini berarti bahwa $p<\alpha$, ada pengaruh yang sangat signifikan pemberian telur sarang laba-laba dengan kecepatan penyembuhan luka tikus putih jantan.

Hasil ini sesuai dengan penelitian yang telah dilakukan oleh Kumar dkk. (2005) yang mengemukakan bahwa penggunaan salep jaring laba-laba yang diaplikasikan pada luka di kulit dapat mempercepat penyembuhan luka (15). Penyembuhan luka dengan penggunaan salep jaring laba-laba disebabkan peningkatan jumah sel fibroblas, sintesis kolagen, kekuatan tensile, kontraksi luka dan periode epitelisasi. Aksi penyembuhan luka terjadi karena kandungan protein yang ada pada jaring labalaba. Menurut hasil penelitian (Brown, 2011) membuktikan bahwa jaring telur laba-laba berpotensi melawan infeksi, menyembuhkan luka, dan membendung darah yang keluar(16). Hal ini sesuai dengan penelitian yang telah kami lakukan, luka tikus putih jantan lebih cepat sembuh akibat pemberian satang telur labalaba.

\section{KESIMPULAN}

Ada pengaruh pemberian sarang telur laba-laba (spider silk protein) secara topikal terhadap proses penyembuhan luka insisi pada fase inflamasi pada tikus putih (Rattus norvegicus wistar). Jumlah tikus yang inflamasi pada kelompok perlakuan lebih sedikit daripada kelompok kontrol, dan tikus yang mengalami perlakuan juga mengalami penyembuhan luka yang lebih cepat dibandingkan dengan kelompok kontrol. 


\section{DAFTAR PUSTAKA}

1. Sherwood L. 2001. Human physiology: from cell to system, A Division of International Thomson Publishing Inc. pp 402-404.

2. Enoch S and Price P, 2004. Cellular, Molecular, and Biochemical Differences in the Pathophysiology of Healing Between Acute Wounds, Cronic Wounds, and Wound in the Aged. pp 32-33.

3. Sjamsuhidayat $R$ and Jong $D, 2011$. Buku Ajar IImu Bedah. Edisi 3, Penerbit Buku Kedokteran EGC, Jakarta. pp 395-399.

4. Gosain, A and DiPietro, LA, 2004. Aging and Wound Healing. World Journal of Surgery, 28(3), 321-326.

5. Perdanakusuma D, 2007, From Caring to Curing Pause Before You Use Gauze, Airlangga University School of Medicine, Surabaya.

6. Mustoe TA, O'Shaughnessy K, and Kloeters 0,2006 . Chronic wound pathogenesis and current treatment strategies: a unifying hypothesis. J Plast Reconstr Surg. 117:35-41.

7. Henderson EA, 2006. The potential effect of fibroblast senescence on wound healing and the chronic wound environment. J Wound Care.15:315-318.

8. Menke $\mathrm{N}$, Ward $\mathrm{K}$, Witten $\mathrm{T}$, Bonchev $\mathrm{D}$, Diegelman R, 2007, Impaired wound healing. Clin Dermatol. 25:19 25.

9. BPOM Rl, 2010, Acuan Sediaan Herbal, Volume Lima, Badan Pengawasan Obat dan Makanan, Jakarta.

10. WHO.Traditional Medicine 2003. Availble from: http://www.who.int/mediacentre/facts

11. Tammelin A, Lindholm C, and Hambraeus A, 2002 Chronic ulcers and antibiotic treatment. J Wound Care. 7:435437.

12. Howell JRS, Wilson MJ, Hill KE, Howard AJ, Price PE, Thomas DW, 2005. A review of the microbiology, antibiotic usage and resistance in chronic skin wounds. J Antimicrob Chemother; 55:143-9.
13. Isrofah, Sagiran dan Afandi $M$, Efektifitas Salep Ekstrak Daun Binahong (Anredera Cordifolia Ten Steenis) Terhadap Proses Penyembuhan Luka Bakar Derajat 2 Termal pada Tikus Putih (Rattus Novergicus). Muhammadiyah Journal of Nursing

14. Wirastuty RY, 2016, Uji efektifitas gel ekstrak kulit batang kayu jawa (Lannea Coromandelica) pada kelinci (Oryctolagus Cuniculuis) Sebagai obat penyembuh luka bakar, Journal ofPharmaceutical Science and Herbal Technology Vol.1 No.1

15. Kumar, 2005. Spider's silk: Investigation of spinning process, web material and its properties. Biological Sciences and Bioengineering. IIT. Kanpur.

16. Bryant R, 2007. Acute and cronic wound. Current Management Concept Philadel phia: M osby Elsevier. P 125. 